\title{
Studi Awal Pembuatan Sistem Sensor Pengukuran Regangan suatu Bahan menggunakan Fiber Optik Plastik Berbasis Data Akuisisi
}

\author{
Prabowo Puranto, ${ }^{*}$ Resetiana D. D., Eni Sugiarti, Tomi B.W., dan Edi T.A. \\ Pusat Penelitian Fisika-Lembaga Ilmu Pengetahuan Indonesia (LIPI) \\ Komplek PUSPIPTEK, Cisauk, Tangerang, Banten
}

\begin{abstract}
Intisari
Telah dibuat suatu sistem pengukuran regangan bahan berdasarkan perubahan intensitas cahaya yang terdeteksi pada fiber optik. Permukaan fiber optik dimodifikasi sehingga mampu mendeteksi perubahan yang dialami selama proses perlakuan. Sistem ini menggunakan sumber cahaya, fotodetektor (PD), pengkondisi sinyal dan modul akuisisi data (DAQ). Sumber cahaya dimasukkan ke dalam pangkal fiber optik plastik dan dideteksi keluarannya pada ujung fiber optik plastik oleh PD. Suatu DAQ dengan resolusi 12 bit diatur dengan perangkat lunak untuk mengukur tegangan PD yang sebanding dengan intensitas sinar laser. Proses uji tarik terhadap suatu spesimen uji yang direkatkan fiber optik plastik telah dilakukan dengan menggunakan Universal Tensile Meter (UTM). Tegangan PD dibaca secara simultan oleh DAQ dan ditampilkan dalam bentuk grafik. Seluruh proses akuisisi data dan tampilan grafik dihasilkan secara otomatis dan disimpan dalam database sehingga memudahkan penggunaan sistem sensor ini.
\end{abstract}

KATA KUNCI: regangan, Universal Tensile Meter (UTM), fiber optik plastik, DAQ

\section{PENDAHULUAN}

Pemanfaatan fiber optik telah dilakukan sejak tahun 1970 sebagai media komunikasi yang mentransmisikan cahaya dalam bentuk pulsa-pulsa informasi. Hal ini dilakukan sejak ditemukannya low-loss fiber, sehingga fiber optik kini banyak digunakan sebagai media transmisi komunikasi dibandingkan dengan kabel tembaga. Selain sebagai media komunikasi fiber optik telah diaplikasikan juga di bidang sensor [1]. Fiber optik plastik adalah salah satu yang diaplikasikan sebagai sensor karena ringan, fleksibel, relatif murah dan pada prinsipnya setiap fiber optik tidak terganggu oleh medan elektromagnet karena hanya mentranmisikan cahaya $[2,3]$.

Berbagai sistem sensor fiber optik telah diteliti dan diaplikasikan untuk berbagai macam pengukuran fisis, diantaranya untuk pengukuran temperatur, getaran, perubahan jarak, indeks bias cairan dan juga regangan suatu bahan. Sistem fiber optik yang telah ada ini adalah sensor EFPI (Extrinsic Fabry Perot Interferometer) dan sensor FBG (Fibre Bragg Grating) [4-6] yang menggunakan fiber ragam tunggal. Selain kedua sistem fiber ini masih banyak lagi sistem fiber optik sensor lainnya yang terus dikembangkan untuk mendapatkan suatu sistem yang peka, akurat, murah, kompak dan fleksibel.

Dengan karakteristik fiber optik sensor yang telah dipaparkan di atas tentunya akan sangat bermanfaat untuk merancang suatu sistem sensor dengan sistem yang lebih sederhana. Oleh karena itu, pada tulisan ini akan disampaikan suatu aplikasi sensor yang memanfaatkan fiber optik sensor

*E-MAIL: prab001@lipi.go.id berjenis fiber optik plastik [7,8] sebagai komponen elemen pengindera perubahan regangan suatu bahan akibat tarikan atupun lekukan. Fiber optik plastik ini dimodifikasi dengan melukai suatu daerah di bagian permukaannya. Hal ini penting dilakukan untuk meningkatkan sensitifitas dari fiber optik terhadap perubahan geometri akibat lekukan atau pun tarikan. Sistem ini dirancang untuk menyederhanakan sistem sebelumnya karena tidak membutuhkan teknik demodulasi untuk mengolah sinyal dengan menggunakan penganalisa spektrum optik, melainkan hanya membutuhkan peralatan seperti transmitter dan receiver yang dalam hal ini adalah sumber cahaya dan fotodioda.

Pengembangan selanjutnya sensor fiber optik plastik ini kemudian akan mengarah kepada Embeded Fibre Optic Sensor yang digunakan untuk mengetahui pergeseran simultan pada jembatan, mengetahui getaran komponen inti struktur bangunan, memonitor terjadinya kerusakan bangunan, mengetahui kesalahan lokasi dari bentuk bangunan, mengetahui dampak lokasi dan pengukuran besaran bangunan, konstruksi beban dan memantau kondisi tekanan angin pada bangunan $[9,10]$. Salah satu cara yang dapat digunakan untuk mengetahui kondisi struktur bangunan dan besaran-besaran tersebut adalah dengan melakukan pengukuran regangan dan pembengkokan pada objek yang akan diukur.

\section{TEORI}

Fiber optik plastik merupakan suatu bahan yang terdiri dari inti yang diselubungi oleh suatu bahan yang indek biasnya lebih rendah dari inti, sehingga cahaya dapat melalui sepanjang inti fiber tersebut akibat proses pemantulan sem- 


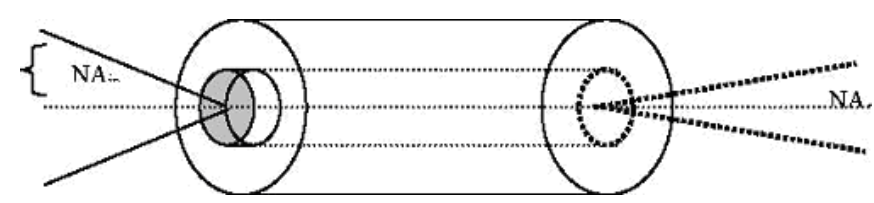

Gambar 1: Definisi dari Numerical Aperture

purna [1]. Jika fiber optik kemudian dilekukkan maka akan mempengaruhi sifat/properties Numerical Apertur (NA) dari fiber. Persamaan praktis [11] untuk proses ini dinyatakan dengan :

$$
N A_{\text {out }}=\sin \theta_{a}=\sqrt{n_{1}^{2}-n_{2}^{2}\left(1+\frac{2 a}{2 R}\right)^{2}}
$$

dengan $\mathrm{n}_{1}$ adalah indek bias inti fiber optik, $\mathrm{n}_{2}$ adalah indek bias selubung, a adalah kelengkungan jari-jari fiber optik dan $\mathrm{R}$ adalah kelengkungan fiber itu sendiri. Kelengkungan inilah yang kemudian dapat dideteksi sebagai ukuran perubahan yang terjadi pada fiber, dimana intensitas cahaya yang masuk dan keluar juga akan mengalami perubahan.

Jika proses kelengkungan ini kemudian digunakan untuk mendeteksi perubahan pergeseran maka fiber ini akan dimungkinkan untuk mengukur besarnya proses regangan yang terjadi, regangan ini dinyatakan sebagai :

$$
\epsilon=\frac{\Delta L}{L}
$$

dengan $\Delta L$ adalah perubahan panjang dan $\mathrm{L}$ adalah panjang awal. Jika fiber optik plastik ini sangat sensitif dengan perubahan terhadap perlakuan pada fiber, maka tentunya fiber ini dapat mendeteksi regangan, yang pada umumnya sangat kecil, yang terjadi.

Fiber optik plastik memiliki beberapa parameter diantaranya atenuasi, numerical aperture, bandwidth, resistansi temperatur, resistansi tarik, resistansi tekan, dan resistansi putar. Resistansi tarik merupakan salah satu hal yang harus dipertimbangkan untuk penelitian ini, dimana pada jenis fiber yang digunakan adalah jenis fiber PMMA (Polymethyl Methacrylate) yang memiliki titik deformasi pada pertambahan panjang $10 \%$ dari panjang awal dan titik putus pada petambahan panjang $80 \%$ dari panjang awal [7].

\section{METODE PENELITIAN}

Penelitian ini dimaksudkan untuk memanfaatkan suatu sistem pengukuran menggunakan fiber optik plastik dengan teknik yang lebih mudah dan dengan biaya yang relatif murah. Prinsip pengukuran ini didasarkan pada pengukuran perbedaan intensitas cahaya yang masuk melalui pangkal fiber optik terhadap cahaya yang keluar dari ujung fiber optik. Perubahan intensitas cahaya ini terutama disebabkan oleh perlakuan terhadap fiber, misal dengan lekukan dan tarikan.

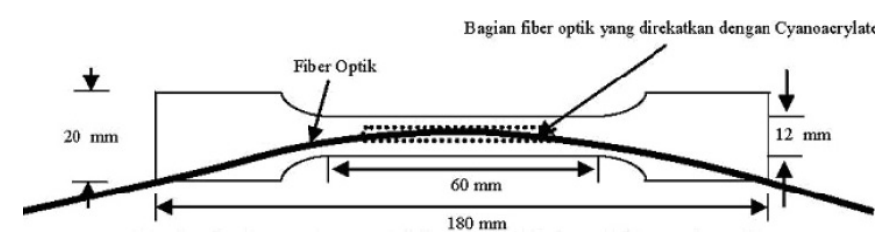

Gambar 2: Ukuran dan bentuk spesimen uji A5052 Aluminium Alloy

\section{A. Spesimen Uji}

Spesimen uji menggunakan spesimen uji berjenis Allumunium Alloy A5052 yang dibentuk dengan ukuran standar pengujian regangan aksial. Spesimen ini akan diuji dengan menggunakan mesin Universal Tensile Meter (UTM). Grafik yang dihasilkan dari proses pengujian akan menunjukkan grafik proses regangan terhadap tegangan tarik.

Selama menggunakan UTM untuk pengukuran regangan pada spesimen uji, fiber optik plastik direkatkan pada spesimen uji. Hal ini dilakukan agar fiber optik mengalami proses penarikan yang sebanding dengan yang dialami oleh spesimen uji pada saat proses penarikan berlangsung.

\section{B. Sistem Optik}

Sistem optik yang digunakan pada pengukuran regangan ini diantaranya adalah fiber optik plastik sebagai elemen pengindera, sumber cahaya laser He-Ne 632,5 nm dengan daya 25 $\mathrm{mW}$ serta komponen lensa objektif dengan perbesaran $10 \mathrm{x}$. Pemberian cahaya pada fiber optik dilakukan dengan memfokuskan sinar laser menggunakan lensa objektif sehingga berkas sinar jatuh tepat pada pangkal dari bagian inti (core) fiber optik plastik. Hal ini dilakukan agar seluruh sinar laser dapat tertransimisikan melalui fiber optik.

Peningkatan kepekaan fiber optik plastik terhadap perubahan dilakukan dengan melukai bagian permukaan fiber optik sepanjang $2 \mathrm{~cm}$ searah dengan panjang fiber dan lebar $1 \mathrm{~mm}$, sehingga bagian inti terpotong sedalam 10\%-50\%. Hal ini menyebabkan sinar laser yang melalui daerah tersebut akan keluar, sehingga terjadi kebocoran yang menyebabkan intensitas cahaya pada ujung fiber akan berkurang. Diharapkan daerah ini menjadi suatu daerah yang peka terhadap perubahan lekuk atau pun tarik. Daerah ini lah yang kemudian akan direkatkan pada spesimen uji, dengan berbagai metode, yaitu: lekuk kedalam, keluar dan lurus seperti pada Gambar 3.

\section{Perangkat Keras}

Perangkat keras sistem sensor yang digunakan terdiri dari suatu rangkaian photovoltaic, fotodioda, pengkondisi sinyal, rangkaian penguat, modul akuisisi data dan komputer. Fotodioda digunakan untuk mengkonversi cahaya menjadi besaran listrik yang kemudian dikondisikan menjadi suatu besaran tegangan. Fotodioda yang digunakan adalah Si photodiode S1336 [14] yang memiliki respon spektrum pada 190 


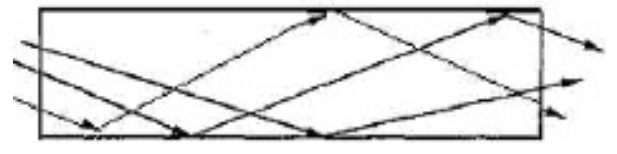

(a)

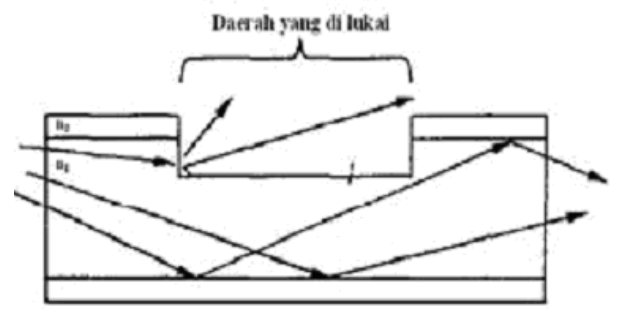

(b)

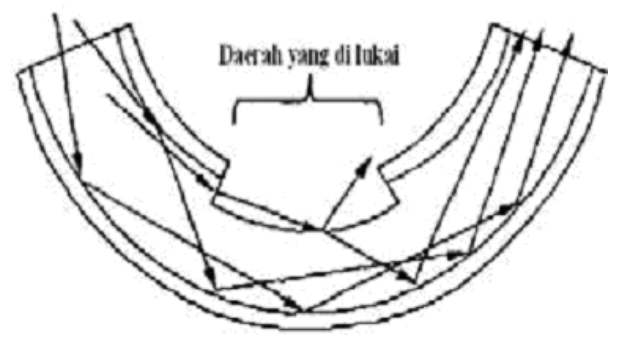

(c)

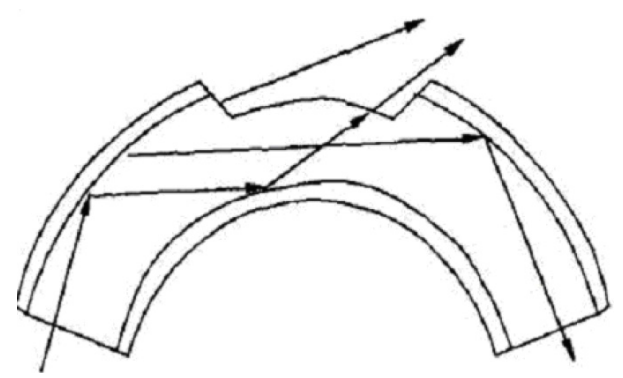

(d)

Gambar 3: Bentuk konfigurasi fiber optik, (a). Lurus dan tidak disayat; (b). Lurus dan disayat; (c). dilekuk ke arah sayatan (kedalam); (d). dilekuk berlawanan arah dari Gambar 3c (keluar)

- $1100 \mathrm{~nm}$ dan puncak respon pada $960 \mathrm{~nm}$ dan sensitivitas $0,1 \mathrm{~A} / \mathrm{W}$. Ujung fiber optik plastik ini kemudian ditempelkan secara langsung pada fotodioda. Rangkaian photovoltaic $[12,13]$ dan amplifier ini lah yang akan menghasilkan suatu nilai tegangan yang besarnya sebanding dengan intensitas sinar laser yang keluar dari ujung fiber dan dapat diukur dengan modul data akuisisi untuk ditransfer kedalam bit-bit digital,disimpan dan diolah oleh komputer.

Suatu rangkaian photovoltaic dirancang sebagai rangkaian pengkondisi sinyal, mengkonversi sinyal yang lemah dari photodiode menjadi sinyal tegangan pada suatu rentang tegangan yang dapat diukur dan dibaca dengan modul DAQ. Rangkaian ini mengkonversi arus yang dihasilkan oleh proses fotoelektrik pada permukaan fotodioda menjadi tegangan yang be-

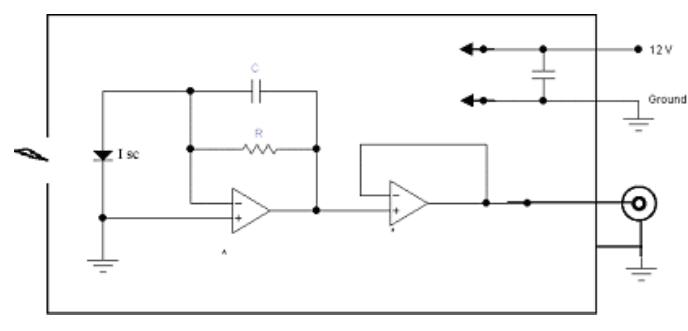

Gambar 4: Rangkaian Tranducer (Photovoltaic)

sarnya adalah $\mathbf{I}_{s c} \times \mathbf{R}$, dengan $\mathrm{I}_{s c}$ adalah arus yang bersumber dari fotodioda, $\mathrm{R}$ adalah resistor umpan balik pada $\mathrm{A}_{1}$, sedangkan $\mathrm{C}$ adalah kapasitor kompensasi untuk mencegah noise akibat komponen kapasitif dari fotodioda. Rangkaian photovoltaic juga diberikan suatu pengikut tegangan yang memiliki penguatan sebesar satu kali, namun memiliki impedansi input tinggi dan impedansi output yang rendah.

\section{Perangkat Lunak}

Perangkat lunak dirancang untuk mengendalikan modul DAQ 12 bit resolusi input analog dengan menggunakan suatu control Active X, AI Sample, yaitu suatu fungsi protokol pengambilan data modul DAQ. Waktu eksekusi pengambilan datanya dapat diatur dengan menggunakan timer yang disediakan pada kode sumber program. Data yang masuk ini akan disimpan dalam suatu database yang juga menggunakan control Active X, ADODC, sebagai antar muka ke database, datadata ini kemudian ditampilkan dalam bentuk grafik. Bentuk alir program ini dapat dilihat pada Gambar 5.

Tampilan perangkat lunak yang terbaca terdiri dari bagian kontrol, indikator, datagrid, database dan visualisasi pengambilan data dalam bentuk grafik. Perangkat lunak ini memudahkan pengguna sistem ini untuk melihat kondisi data secara realtime, sehingga proses pengontrolan dapat dilakukan. Kemudahan yang diberikan pada perangkat lunak yang dibuat selain untuk visualisasi juga digunakan untuk mempermudah proses pengolahan data. Pengolahan data dapat dilakukan secara langsung atau pun dengan program lain seperti Microsoft Excel. Semua data yang diambil dapat dipindahkan secara otomatis dengan menekan tombol Excel, maka seluruh data akan dipindahkan ke program Excel. Selain itu perangkat lunak ini juga disediakan fasilitas "Hapus Database" untuk menghapus seluruh data yang sudah tidak digunakan lagi.

\section{E. Sistem Keseluruhan}

Rancangan sistem keseluruhan merupakan penggabungan sistem optik, perangkat keras dan perangkat lunak untuk melakukan pengukuran regangan. Intensitas cahaya yang keluar dari ujung fiber optik terus dicatat selama proses uji tarik berlangsung. Pengujian dilakukan untuk mengukur bentuk fiber optik yang paling sensitif dan sesuai untuk pengujian tarik (Gambar 3). Sistem keseluruhan ini kemudian diuji un- 


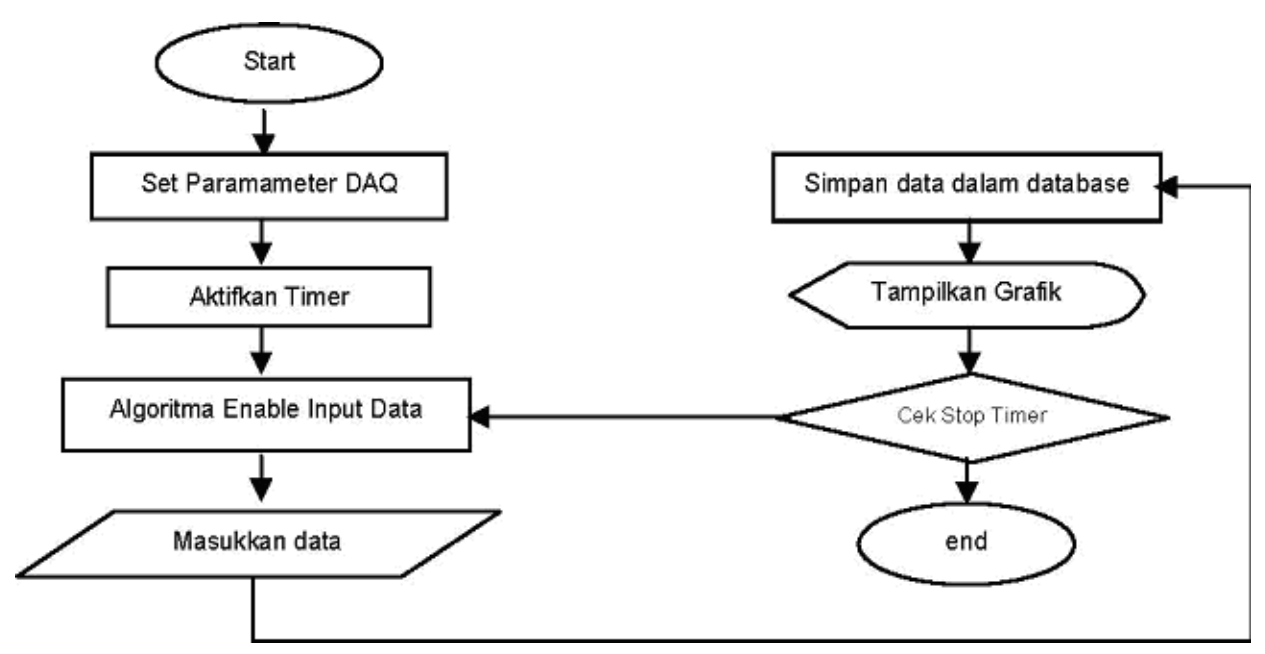

Gambar 5: Diagram Alir Program

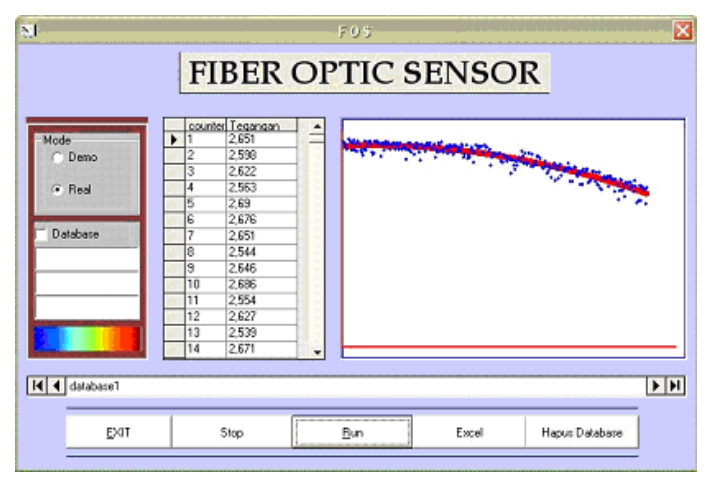

Gambar 6: Tampilan Program Pengambilan Data

tuk mengukur regangan dari spesimen uji, dan dibandingkan dengan grafik yang dihasilkan dari UTM.

\section{HASIL DAN DISKUSI}

Pengujian ini dilakukan dengan dua tahap, dimana pengujian pertama kali ini digunakan untuk mengetahui metode yang paling efektif untuk pengukuran regangan. Pengujian pertama dibagi menjadi tiga metode, yaitu pengukuran intensitas cahaya pada fiber optik yang telah dilukai untuk lekuk kedalam, lekuk keluar dan lurus. Sedangkan pengujian tarik secara langsung terhadap fiber tidak dilakukan karena diperkirakan akan mengganggu repeatability pengukuran, meskipun rata-rata titik deformasi adalah $10 \%$ penguluran dari panjang awal.

\section{A. Hasil Pengujian Konfigurasi Fiber Optik}

Pengujian ini dilakukan dengan mengukur intensitas sinar laser pada daerah fiber optik, yang telah disayat untuk lekuk kedalam, lekuk keluar dan lurus (tanpa dilekuk). Lekukan di- lakukan dengan radius (R) $4 \mathrm{~cm}$ sepanjang $6 \mathrm{~cm}$. Hasil pengujian untuk fiber lurus tanpa silekuk kedalam maupun keluar adalah 2,5 V, sedangkan lekuk kedalam menghasilkan tegangan sebesar 2,6 V yang nilainya hampir mendekati fiber optik yang tidak dilekuk (lurus). Hasil pengukuran pada saat fiber optik dilekuk keluar ternyata intensitas cahaya turun drastis, hal ini dapat dilihat dengan tegangan yang terukur ternyata turun menjadi 1,5 V. Semua grafik pengujian ini dapat dilihat pada Gambar 8.

\section{B. Hasil Pengujian Sistem Keseluruhan}

Setelah pengujian terhadap fiber optik dilakukan, maka dilanjutkan pengujian keseluruhan sistem untuk mengukur regangan dari specimen uji. Pengujian ini dilakukan dengan memilih konfigurasi fiber optik lekuk kedalam karena lebih stabil dibandingkan dengan lekuk keluar. Lingkungan pengujian dengan banyak cahaya dapat mengubah intensitas cahaya melalui bagian fiber yang telah disayat. Dari grafik pengujian dengan UTM didapat besarnya perubahan panjang yang terjadi adalah 5,3 mm, sedangkan pada pengukuran dengan fiber terukur bahwa tegangan pada awal adalah 2,65 volt dan pada saat titik tegangan mencapai $5376 \mathrm{~N}$, tegangan turun dari 2,65 $\mathrm{V}$ ke- $2,05 \mathrm{~V}$.

Dari hasil pengujian ini dapat diambil nilai perbandingan regangan yang terjadi terhadap perubahan tegangan adalah 5,3 $\mathrm{mm} / 0,6 \mathrm{~V}$ atau $8,8 \mathrm{~mm} / \mathrm{V}$ atau sekitar $8,8 \mu \mathrm{m} / \mathrm{mV}$. Dikarenakan keterbatasan dari modul DAQ yang memiliki resolusi 12 bit, maka nilai tegangan yang dapat terbaca dengan kondisi yang optimal adalah pada tiap kenaikan $5 \mathrm{mV}$, sehingga sistem ini terbatas pada pengukuran dari tegangan-tegangan yang kecil. Jika perbandingan adalah $8,8 \mu \mathrm{m} / \mathrm{mV}$ maka $5 \mathrm{mV}$ sama dengan perubahan regangan sekitar $44 \mu \mathrm{m}$. 


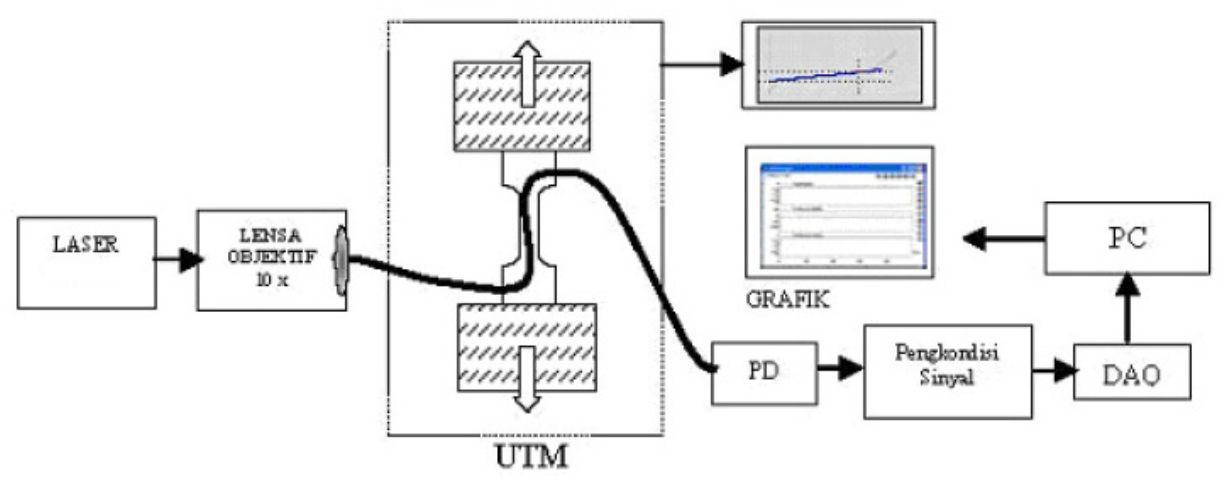

Gambar 7: Skematik sistem uji keseluruhan

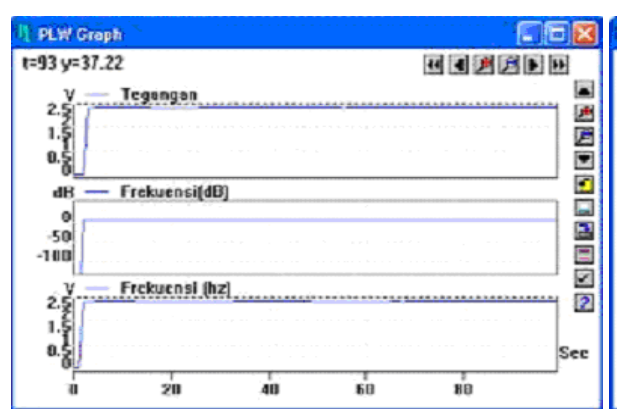

(a)

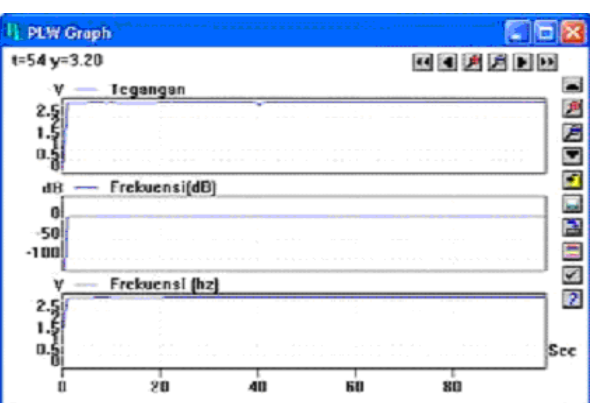

(b)

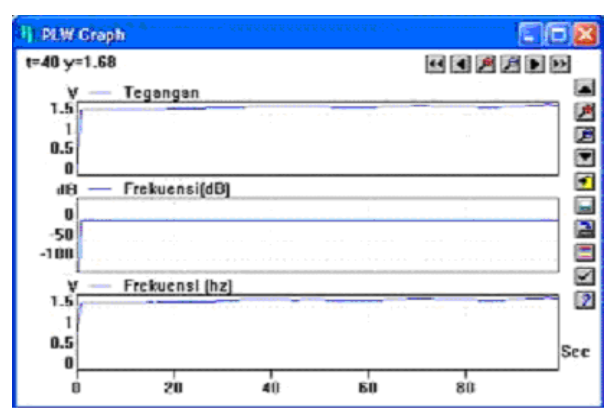

(c)

Gambar 8: Hasil uji konfigurasi fiber optik, (a) Lurus (b) Lekuk kedalam (c) Lekuk keluar

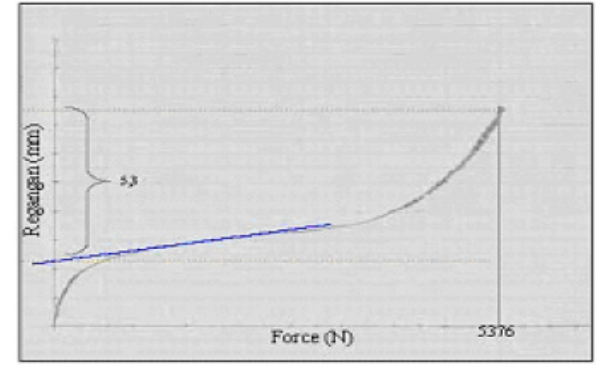

(a) Grafik Uji dengan UTM

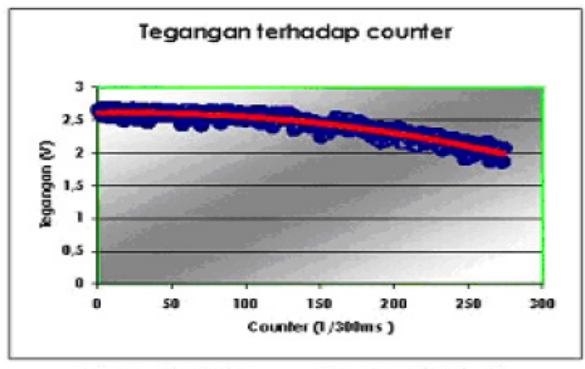

(b) Grafik Uji Dengan Fiber Optik Plastik

Gambar 9: Hasil uji sistem keseluruhan 


\section{SIMPULAN}

Rancangan sistem telah mampu mendeteksi adanya regangan dari pendeteksian suatu perubahan panjang dimana pengujian dipilih dengan metode fiber yang dilekuk kedalam berdasarkan stabilitas dan sensitivitas dari fiber optik. Fiber optik plastik yang dimodifikasi memberikan pengaruh dalam pengindera perubahan lekuk yang terjadi pada fiber, dengan demikian fiber optik plastik dapat dimungkinkan untuk mengukur suatu regangan yang terjadi pada bahan berbasis piranti komponen optik dan piranti elektronika. Rangkaian photovoltaic dirancang untuk mampu mendeteksi peruba- han intensitas cahaya yang sangat kecil, sehingga mampu mengukur adanya perubahan yang terjadi pada fiber tersebut. Modul data aquisisi diatur dengan perangkat lunak untuk mengukur, mengkonversi, mengumpulkan serta mentransfer data ke-komputer sehingga dapat diolah dan ditampilkan dalam bentuk grafik secara realtime. Hasil pengujian dengan sistem keseluruhan menunjukkan adanya perubahan yang dialami oleh fiber selama proses penarikan dengan indikasi turunnya tegangan terukur dari sinar laser yang melalui fiber. Tegangan turun dari 2,6 V menjadi $2 \mathrm{~V}$ dari $5,3 \mathrm{~mm}$ perubahan panjang yang dialami bahan pada proses uji penarikan.
[1] Christian Hentschel, Fiber Optics Handbook, 3rd ed., HawlettPackard GmbH, Boeblingen Germany (1989).

[2] Clifford R. Pollock, Fundamental of Optoelectronics, Prentice Hall International (1992).

[3] John Dakin, Brian Culshaw, Optical Fiber Sensors : Principles and Components, Volume one (1988)

[4] Leng Jinsong dan Anand Asundi, Sensor and Actuators, A 103, 330-340(2003).

[5] M.A Davis, D G Bellemore dan A D Kersey, Distributed Fiber Bragg Grating Strain Sensing in Reinforced Concrete Structural Componenets, PII : S0958 - 9465 (96) 00042-X.

[6] Christopher J Tuck, Richard Hague, Crispin Dyle, Low Cost Optical Fibre Based Fabry Perot Strain Sensor Production (2006)

[7] Club Fibres Optiques Plastiques (France), Plastic Optical Fibres: Practical applications, John Willey \& Sons (1997)

[8] K S C Kuang, W J Cantwell dan P J Scully, Meas.Sci.Technol., 13, 1523-1534 (2002).

[9] Leng Jinsong, D Winter, R A Barnes, G C Mays dan G F Fernando, Smart Mater.Struct., 15, 302-308 (2006).
[10] Kin-tak Lau, Chi-chiu Chan, Lim-min Zhou, dan Wei Jin, Monitoring in Composite-Strenghtened Concrete Structures using Optical Fibre Sensors, Composite:Part B 32 33-45 (2001).

[11] Babchenko A, Z Weinberger, N. Itzkovich and J Maryles, Plastic optical fibre with structural imperfections as a displacement sensor, Dept. Of Applied Physics, Jerussalem College of Technology, Published 13 April 2006, Online at stacks.iop.org/MST/17/1157

[12] Wright P, K B Ozanyan, S J Carey and H McCann, Optimisation of the Signal to Noise Performance of Photodiode Receivers in Near-Infrared Absorption Tomography, Electrical \& Electronic Engineering, UMIST, Manchester, UK.

[13] Application Circuit examples of Si Photodiode, http://sales. hamamatsu.com / assets / applications / SSD / si-pd-circuitexamples.pdf

[14] Si Photodiode, Hamamatsu Photonics K.K., Solid State Division, Available http://www.zdphotonics.com/pdf/Siphotodiode.pdf (tanggal akses: 3 Mei 2007). 